\title{
EVALUATION OF DLC COATING FOR PARTS OF WEAPONS AND MILITARY EQUIPMENT
}

\author{
1Eduard HEGR, ${ }^{2}$ Zbynek STUDENY, ${ }^{3}$ Huu Chien NGUYEN, ${ }^{3}$ Jiri PROCHAZKA, ${ }^{3}$ Jan ADAM \\ 1Brno University of Technology, Czech Republic, EU, +420 734366 134, eduard.hegr@seznam.cz \\ 2University of Defence in Brno, Czech Republic,EU, +420 97344 2604, zbynek.studeny@unob.cz \\ 3University of Defence in Brno, Faculty of Military Technology, Czech Republic, EU,
}

https://doi.org/10.37904/metal.2020.3537

\begin{abstract}
The article deals with tribological evaluation of DLC coating. This coating is deposited on a material which, due to its mechanical properties, is suitable for components of weapons and military equipment. The results of the Department of Engineering of the Faculty of Military Technology of the University of Defense in Brno in the field of plasma nitriding are used in this work. Plasma nitriding technology has been found to have a positive effect on the performance of components operating under extreme conditions. One of the significant surface changes is the increase in surface hardness. Further increases wear resistance and corrosion resistance. By setting the parameters of plasma nitriding technology appropriately, fatigue life can be increased.

Deposition of the DLC coating by PVD technology on a tempered or plasma nitrided surface results in qualitative changes on the surface of the component. Evaluation of tribological properties such as coefficient of friction or wear coefficient can be verified by adjusting surface treatment technologies to specific applications, eg in armaments production.

The paper presents the results of tribological properties of the surface of the DLC coating deposited on substrate of the heat-treated steel 42CrMo4. The comparison was done with the deposition of a DLC coating on the surface substrate of a steel $42 \mathrm{CrMo} 4$ that has been plasma nitrided, like a duplex system. Tribological properties such as friction coefficient and wear coefficient were measured by a Tribolab UMT-3 equipment. Tribological tests such as Scratch test and Ball on Disc were performed on this device.
\end{abstract}

Keywords: DLC coating, Scratch test, Ball on Disc, components of weapons

\section{INTRODUCTION}

Parts of military equipment and weapons are treated with a variety of surface technologies to increase their resistance. These components operate in a specific environment where conditions may be extreme. These conditions are simulated exercises, which are tested not only soldiers, but also the technology they use. In a real combat situation it is then necessary to rely on components of military equipment and weapons. Their function is irreplaceable to accomplish a task by an individual or by a whole military unit.

The structural steel used for these components is heat treated. It is also possible to modify the surface of the component forming or depositing layers of coating. Previous research [1-4] has clearly shown the positive effect of plasma nitriding technology on weapon components such as barrel, breech, etc. Forming a layer of nitrides of the alloying elements to obtain an increase corrosion resistance $[5,6]$, increase abrasion resistance [7-9] or increasing the fatigue properties [10-13] for steels.

Further improved properties, particularly abrasion resistance can be achieved by forming the DLC coating on the surface has been nitrided. The article deals with the study and comparison of the effect of deposited DLC coating on $42 \mathrm{CrMo} 4$ steel, which was only refined or even plasma nitrided. Each operation carried out with the material carries an increase in the financial cost of each component of the weapon or military equipment. It is 
therefore necessary to determine which surface technology is suitable for a particular application or whether combinations of coating and coating technologies are suitable.

The article evaluated the tribological properties of the surface of the DLC coating deposited on the substrate treated steel 42CrMo4. Furthermore, a DLC coating deposited on a diffusion layer created by plasma nitriding technology on $42 \mathrm{CrMo} 4$ steel. There were performed Scratch test and Ball on disc tests. Subsequently, the coefficient of friction and wear coefficient were evaluated. Studying the properties of coatings brings valuable knowledge into the process of acquisition and introduction of military equipment into the Army of the Czech Republic.

\section{MATERIAL AND SAMPLE PREPARATION}

The object of the experiment was samples of $42 \mathrm{CrMo} 4$ steel. These samples were coated with DLC by PVD technology as required. For sample A, the DLC coating was deposited in a duplex system. The diffusion layer of iron nitrides and alloying elements was the basis for the coating of Sample A. This layer was created by plasma nitriding technology. For sample B, a DLC coating was deposited on the base material (substrate).

Experimental samples used for testing were made according to the procedures of the Department of Mechanical Engineering in accordance with the field of metallographic preparation. Quality sample preparation is a critical step to achieving the objective results not only in assessing the metallurgical structure, but also in the areas of chemical composition analysis and tribological characteristics. The experimental samples were divided by the Struers grinding wheel on a metallographic circular saw LECO VIPER-300M2.

Separated parts from each of the supplied samples were hot pressed into Struers Isofast molding material on a LECO RR-4X metallographic press at $2600 \mathrm{kPa}$. Pressing was carried out for 4 minutes at $180^{\circ} \mathrm{C}$. After pressing each sample was described and its surface has been mechanically cut to semi-universal grinder / polisher COMPACT $1031 \mathrm{MTH}$. HERMES abrasive papers with grain size 80, 120, 240, 400, 600, 1000 and 2000 according to the European FEPA marking were used as abrasives. The samples were polished on LECO Brown Technotron abrasive cloth, using LECO PREMIUM GRADE diamond paste with a particle size of $3 \mu \mathrm{m}$ and $1 \mu \mathrm{m}$. After polishing, the sample was ultrasonically cleaned in a POLSONIC-2 instrument.

Cross-section samples were then used to evaluate the microstructure and chemical composition of the OES method on a Tasman Q4.

Table 1 - Analysis of chemical composition of substrate and its comparison with standard

\begin{tabular}{|l|l|l|l|l|l|l|l|l|l|}
\hline \multicolumn{10}{|c|}{ Content of elements (wt. \%) } \\
\hline C & Mn & Si & Cr & Mo & Ni & P & S & Cu & Al \\
\hline 0.54 & 0.65 & 0.249 & 1.045 & 0.149 & 0.128 & 0.005 & 0.15 & 0.176 & 0.016 \\
\hline \multicolumn{8}{|c|}{ Recommended values from ČSN EN 10083-1 42CrMo4 steel } \\
\hline 0.38 & 0.60 & $<0.40$ & 0.90 & 0.15 & --- & $<0.035$ & $<0.035$ & $\cdots$ & $\cdots$ \\
0.45 & 0.90 & & 1.20 & 0.30 & --- & & & \\
\hline
\end{tabular}

After the NITAL solution etching operation, the microstructure of the samples is shown in a 3D inverted optodigital microscope view of the OLYMPUS DSX 500 in Figure 1a and Figure 1b, respectively. The documented microstructure shows that it is a martensitic structure with residual austenite of very fine manganese carbides and sulfides. This microstructure corresponds to a quenched and tempered state performed in accordance with the relevant material sheet for $42 \mathrm{CrMo} 4$ steel.

The mean DLC coating thickness of Sample A in Figure 1a is $1,44 \pm 0,15 \mu \mathrm{m}$. The measurement was performed at nine points. By measuring the microhardness course on a LM 247 AT LECO equipped with AMH 55 LECO software, a diffusion layer depth of $245 \mu \mathrm{m}$ was found in Sample A. 
The DLC coating thickness of Sample B in Figure $\mathbf{1 b}$ was lower than that Sample A. After seven measurements, the coating thickness value was determined as $0,78 \pm 0,11 \mu \mathrm{m}$. A thin chrome coating was deposited under both of the DLC coatings. The chrome coating is used to increase adhesion.

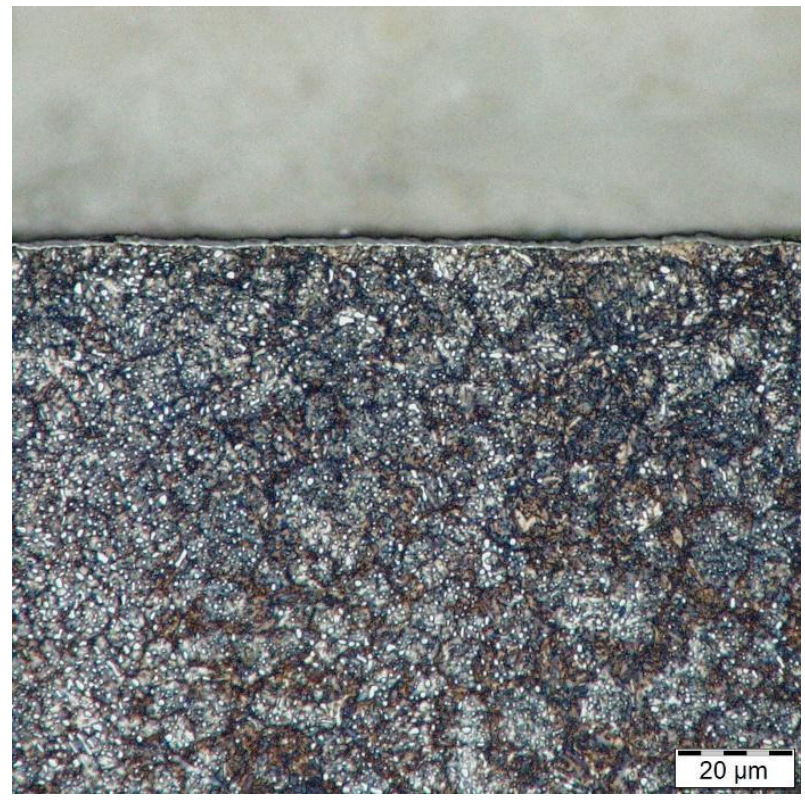

Figure 1 a Microstructure of Sample A PN + DLC Duplex System

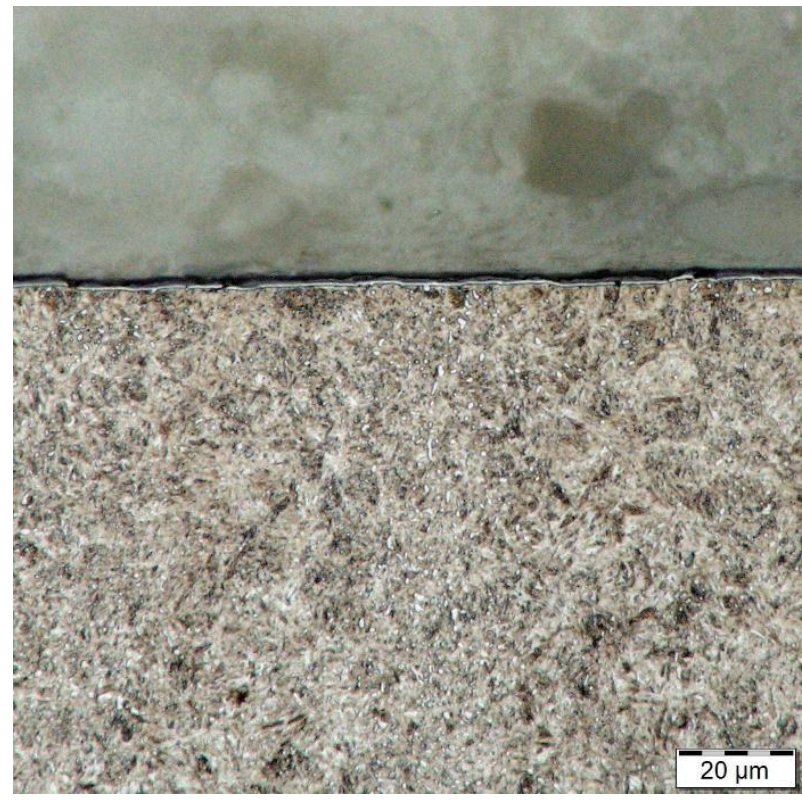

Figure 1 b Microstructure of Sample B coated with DLC

\section{EXPERIMENT}

Experimental samples were made in the form of flat discs. These samples were made according to the requirements for ball on disc testing on a Bruker UMT-3 tribometer. Subsequently, a scratch test was performed on the same samples to determine the coating parameters - duplex coating and layer system, respectively.

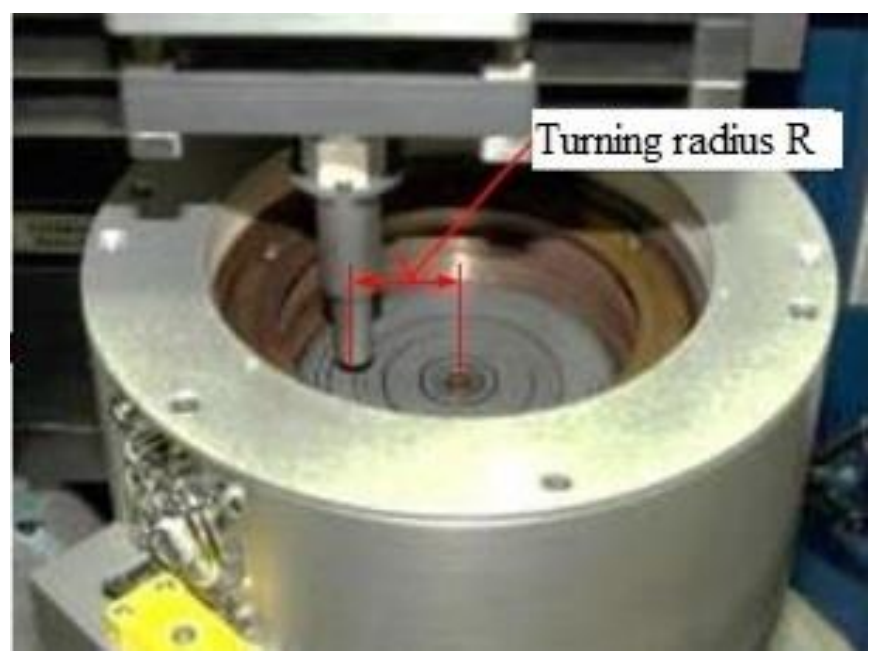

Figure 2 Ball on Disc method

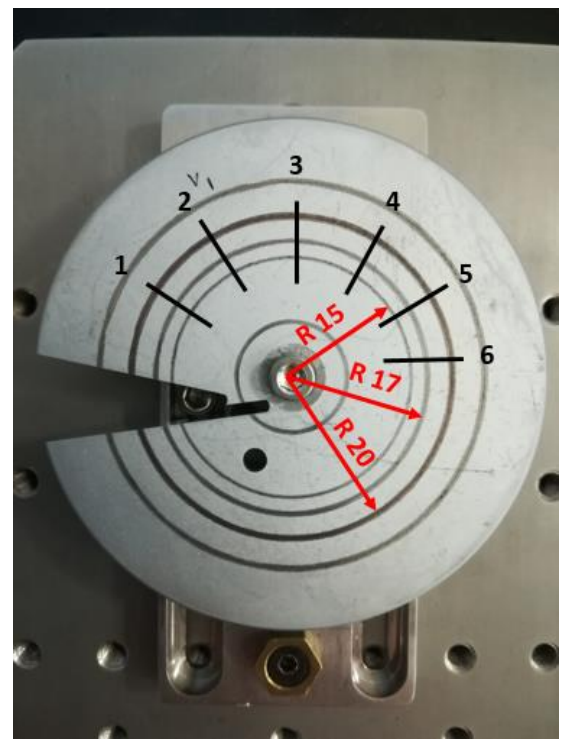

Figure 3 Places of measurement on samples $A$ and $B$ and tests radius 
The measurement of the coefficient of friction by the "Ball on Disc" method [14] (see Figure 2) is based on the contact of a stationary indentor pressed by a constant force on the measured surface of the rotating sample. The ball-shaped indentor is mounted in the holder and the rotary disk-shaped test specimen is clamped in the turntable. The friction force is exerted between the indentor and the sample, and its value is systematically evaluated in the area of the indentor clamping.

The generated traces are proportional to wear, which is due to the rotation of the sample application and pressing force on the indentor. This track is analyzed and evaluated in the next measuring step. The value of the wear coefficient is determined on the basis of the applied values and the results of the trace measurement according to the relation [15]:

$$
\mathrm{K}=\frac{\sum_{1}^{\mathrm{n}} \mathrm{A}_{\mathrm{pn}}}{\mathrm{n}} \cdot \frac{1}{\mathrm{~F}_{\mathrm{N}} \cdot \omega \cdot \mathrm{t}},
$$

where: $\mathrm{K}$ is the wear coefficient $\left[\mathrm{mm}^{-3} \cdot \mathrm{N}^{-1} \cdot \mathrm{m}^{-1}\right]$,

$\mathrm{n}$ is the number of track measurements (6 measurements [15] are performed within the article, see Figure 3),

$A_{p n}$ is the number of surface area of the wear trace $\left[\mathrm{mm}^{2}\right]$,

$\mathrm{F}_{\mathrm{N}}$ is the normal force $[\mathrm{N}]$,

$\omega$ is the sample rotation speed $\left[\mathrm{min}^{-1}\right]$,

$t$ is the duration of the measurement [min].

The tribological properties were measured according to the following conditions:

- a ball-shaped indentor of $6,3 \mathrm{~mm}$ diameter is made of hardened steel $100 \mathrm{Cr} 6$ with a hardness of 62 HRC,

- $\quad$ the temperature of the test and indentor measurements was $21^{\circ} \mathrm{C}$,

- tests were carried out without lubrication (dry friction),

- the radius of rotation, i.e. the distance from the measurement contact point to the axis of rotation of the disk was $(15,17$ and 20$) \mathrm{mm}$ with a load $\mathrm{F}_{\mathrm{N}}(5,20$ and 50) $\mathrm{N}$,

- $\quad$ relative speed $v=100 \mathrm{~mm} \cdot \mathrm{s}^{-1}$, total distance $\mathrm{s}=500 \mathrm{~m}$, measuring time $\mathrm{t}=83,33 \mathrm{~min}$.

Scratch test was performed on experimental samples. This test is one of the basic methods of monitoring the adhesion of the coating system - substrate, respective coating - layer - substrate [15]. The principle of the method is loading the indentor, which moves horizontally. The indentor was loaded continuously with increasing force in the range of $(0-190) \mathrm{N}$ on the track with $=10 \mathrm{~mm}$ speed $\mathrm{v}=1 \mathrm{~mm} \cdot \mathrm{s}^{-1}$. A scratch was formed by penetrating the indentor into the sample. This generates a stress at the interface which, when the critical value is reached, causes the coating to tear off from the substrate. The tribometer recorded the course of the normal $F_{N}$ and the tangential force $F_{t}$ acting on the indentor, the friction coefficient values and the acoustic emission signal [16].

\section{RESULTS AND DISCUSSION}

\subsection{Ball on disc}

To evaluate the coefficient of friction, it is necessary to state that it is a dimensionless quantity defined as the ratio of normal and frictional forces. This value is influenced by the surface condition of the sample path outdated indenter, respective measurement time, environmental and other influences. The coefficient of friction also depends on the roughness of the surface. Due to the influence of surface irregularities, the contact surface of the indentor-test sample pair changes as the load changes. 
When evaluating the friction coefficient, the average value measured in the "stable" part of the friction coefficient recording as a function of the measurement time is usually taken as its value. The average values from the friction coefficient measurements with the standard deviations of all samples are summarized in

Table 2.

Table 2 Friction coefficient values

\begin{tabular}{|c|c|c|c|}
\hline Sample identification & 5 N load & 20 N load & 50 N load \\
\hline A (PN + DLC) & $0.1164 \pm 0.01261$ & $0.1024 \pm 0.00252$ & $0.1129 \pm 0.01869$ \\
\hline$B(D L C)$ & $0.1075 \pm 0.01148$ & $0.1047 \pm 0.005911$ & $0.1049 \pm 0.0148$ \\
\hline
\end{tabular}

Figure 4a shows the friction coefficients of all applied load values of the PN + DLC coating duplex system (sample A). The process of the friction coefficient only for the DLC coating (sample B) is shown in Figure $\mathbf{4 b}$. It can be stated that both the PN + DLC coating duplex system and the DLC coating alone have a stable coefficient of friction throughout the test. The DLC coating was not significantly damaged during the test.

Table 3 Wear measurement parameters

\begin{tabular}{|c|c|c|c|c|}
\hline Sensor type & Range & \multicolumn{2}{|c|}{ Resolution } & \multirow{2}{*}{ Scanning speed } \\
\hline \multirow{2}{*}{$\begin{array}{c}\text { Inductive sensor, DIA R2 } \\
\mu \mathrm{m}\end{array}$} & \multirow{2}{*}{$500 \mu \mathrm{m}$} & vertically & transverse & \multirow{2}{*}{$500 \mu \mathrm{m}_{\mathrm{s}}^{-1}$} \\
\cline { 3 - 4 } & $10 \mathrm{~nm}$ & $2 \mu \mathrm{m}$ & \\
\hline
\end{tabular}

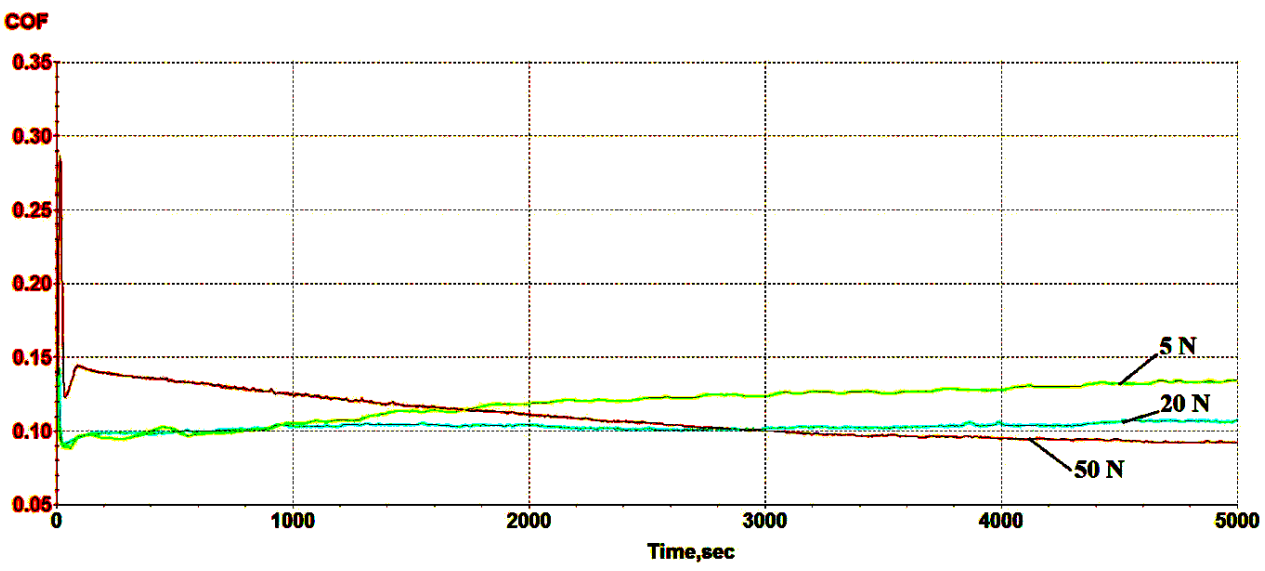

Figure 4a The process of the coefficient of friction for sample $A(P N+D L C)$

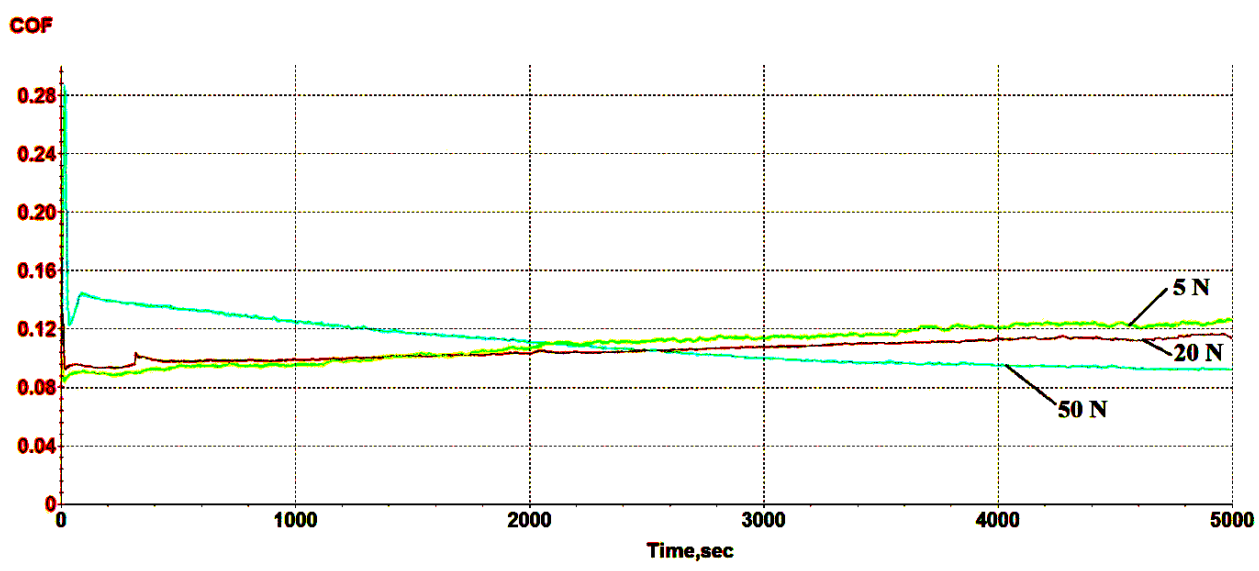

Figure $\mathbf{4 b}$ The process of the coefficient of friction for sample $B(D L C)$ 
The measurement traces of wear were carried out on a universal instrument for measuring surface texture Talysurf CLI 1000 using the inductive touch method. Wear stop parameters were evaluated using TalyMap 5.1 software. The measurement parameters are shown in Table 3. The measured length was $10 \mathrm{~mm}$ with a $3 \mu \mathrm{m}$ data acquisition step. All three tracks with selected radii and loads were analyzed in one measurement (scanning indentor crossing).

Table 4 Wear coefficient values

\begin{tabular}{|c|c|c|c|}
\hline Sample identification & $\mathbf{5}$ N load & $\mathbf{2 0} \mathbf{N}$ load & $\mathbf{5 0} \mathbf{~}$ load \\
\hline A (PN + DLC) & $3.07 \mathrm{E}-09$ & $1.50 \mathrm{E}-09$ & $2.59 \mathrm{E}-09$ \\
\hline B (DLC) & $8.40 \mathrm{E}-10$ & $8.06 \mathrm{E}-10$ & $6.05 \mathrm{E}-10$ \\
\hline
\end{tabular}

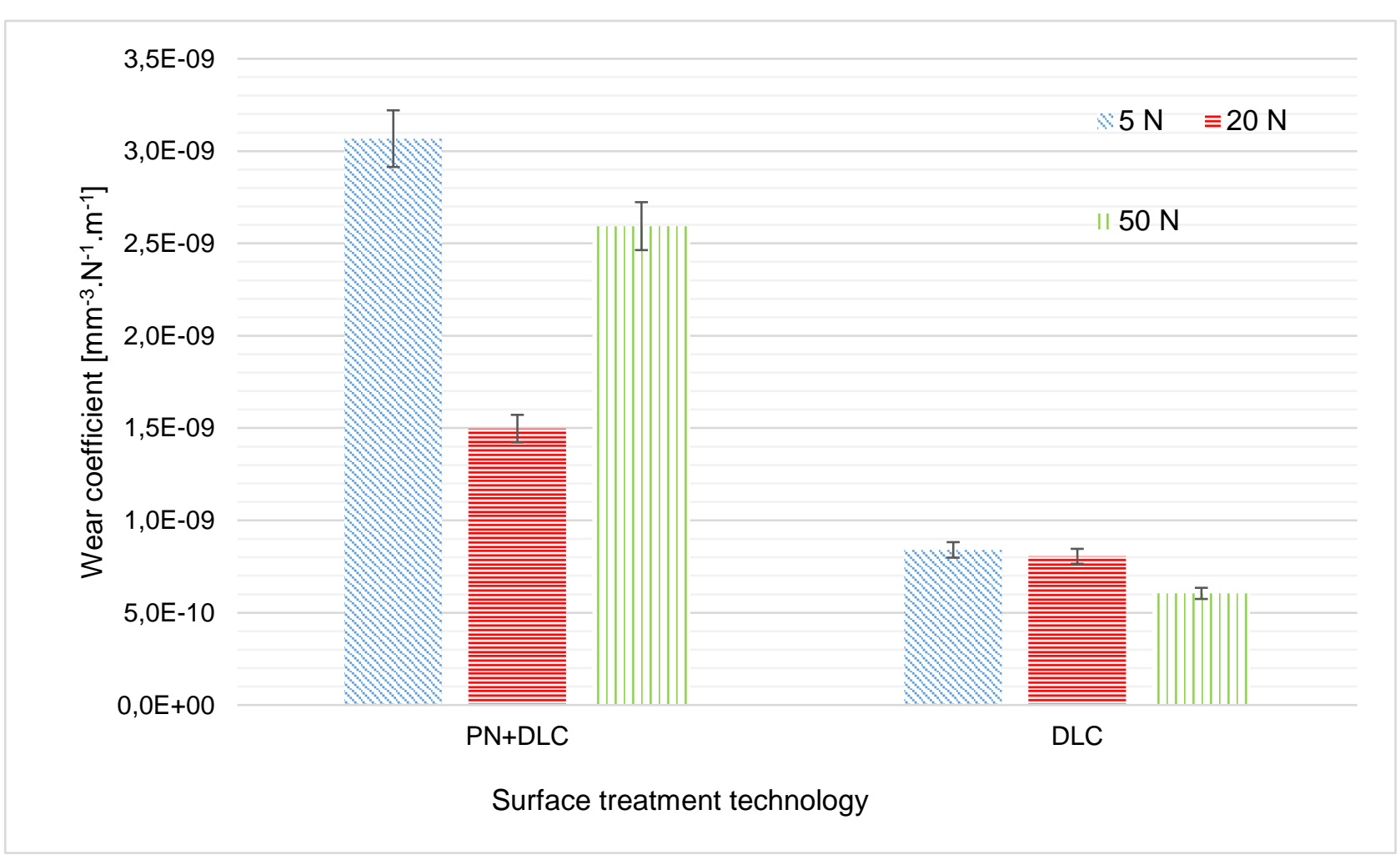

Figure 5 Wear coefficient values

As can be seen from the graphical representation of the wear coefficient values in Table 4 or Figure 5, the DLC coated sample $B$ has the lowest wear values at all applied load values. This result is consistent with the test progress, the state of the test tracks, and the scratch test results. However, very similar values of wear coefficient were achieved with sample A with the PN + DLC duplex system. The measured difference in specific values may be within the accuracy when measuring the trace contents, which were very difficult to identify for both samples due to their small relative dimensions within the topography of the sample surface.

\subsection{Scratch test}

The Scratch test was run on a $10 \mathrm{~mm}$ path under a linearly increasing force in the range of $(0-190) \mathrm{N}$. The results are records of the loading force, acoustic emission signal and the coefficient of friction. The critical loads show the forces at which the DLC coating and the duplex coating system rupture the coating and subsequently break the coating. 


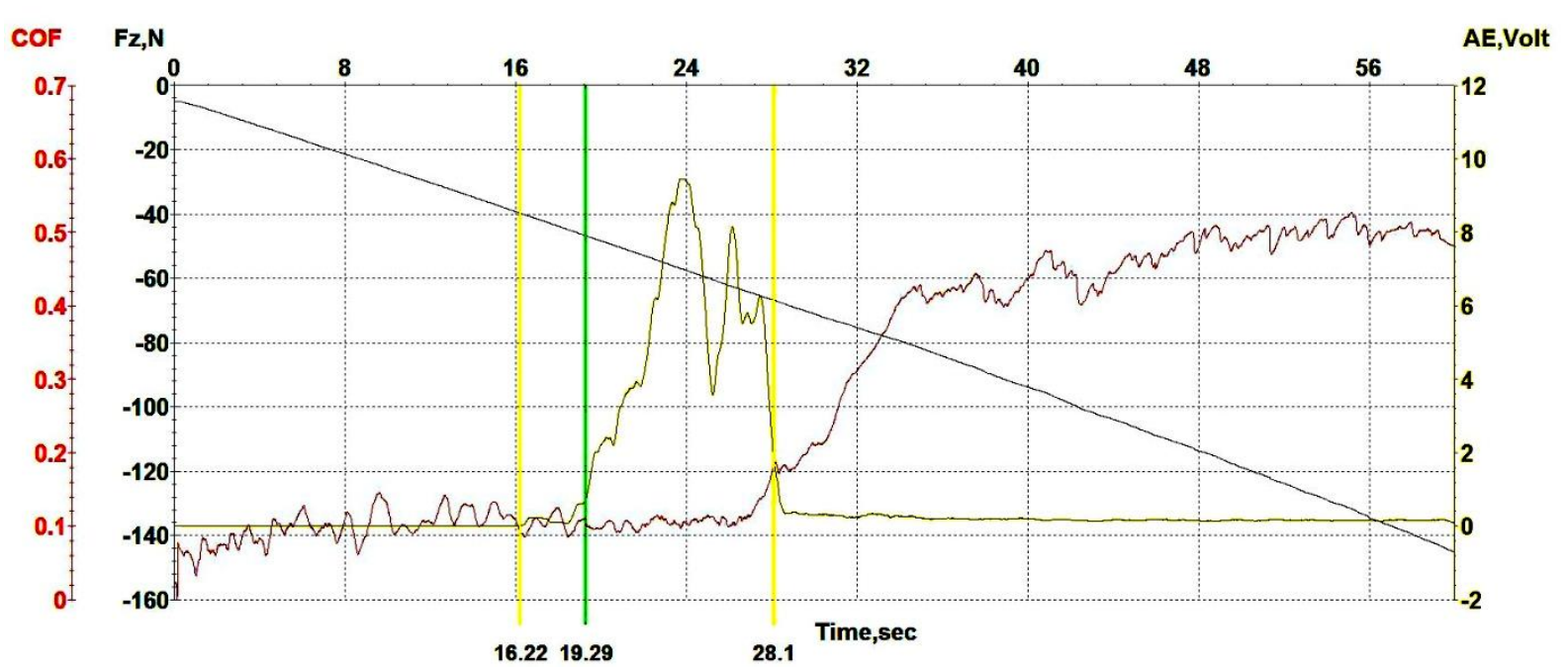

Figure 6 The critical loads Sample A (PN + DLC)

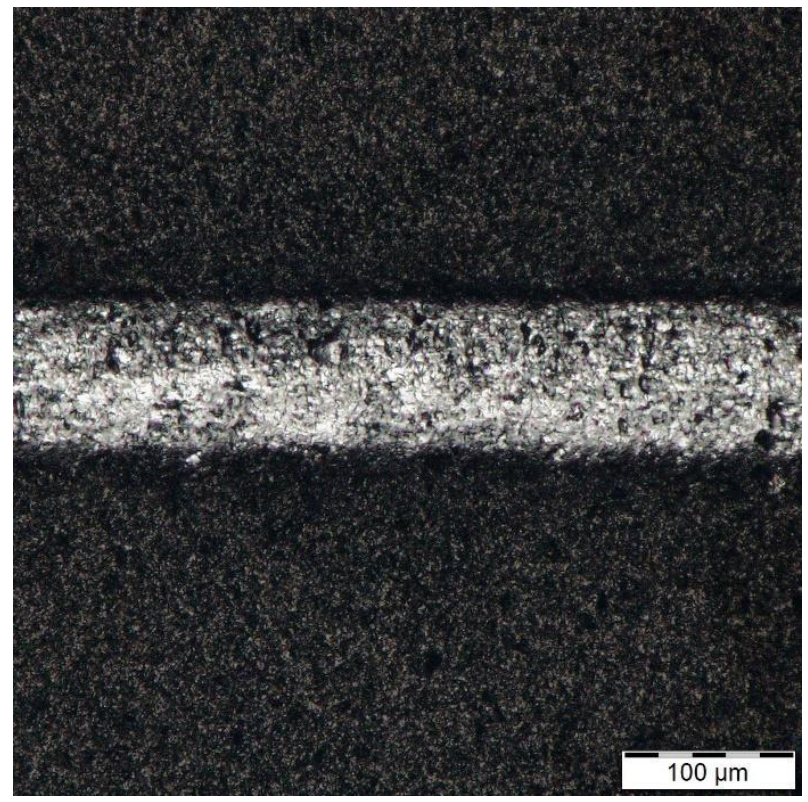

Figure 7 Sample A (PN+DLC), 1st critical point

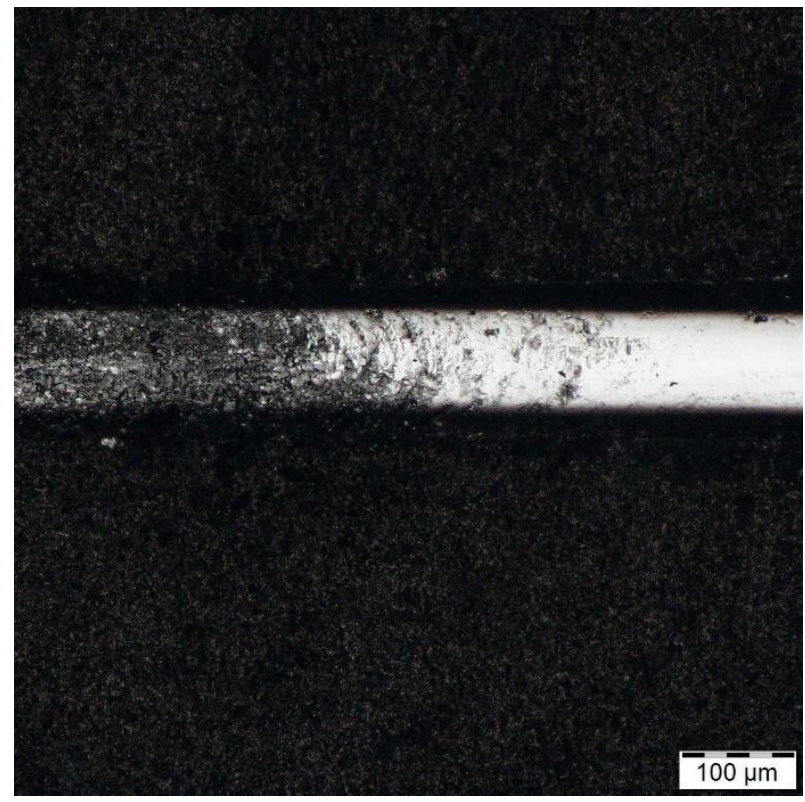

Figure 8 Sample A (PN+DLC), 2nd critical point

From the test record in Figure 6 and for Sample A, a duplex plasma nitriding and DLC coating system, the rupture and breakthrough values of the coating are evident. In this record in Figure 6, the acoustic emission curve intersects with a linear course of increasing load force. Since this is a compressive force, it is marked with a negative sign in the tribometer and the waveform is expressed downwards. Rupture of the coating was $40 \mathrm{~N}$, and break of the coating on the base material was $71 \mathrm{~N}$. The rupture and breakage values of the coating were obtained as the mean of the three measurements.

The course of the scratch test and its recording for DLC coated sample B is illustrated in Figure 9. The rupture and breakage of the coating are here at a higher critical load than the previous DLC coated sample. This is probably due to the substrate layer obtained by the plasma nitriding process. The rupture values of the coating correspond to a critical force of $54 \mathrm{~N}$ and the breaking values of the coating to a critical force of $94 \mathrm{~N}$. In the Figures 10 and 11, images of the indentor trace after the scratch test are shown. The rupture and breakage values of the test samples are shown in Table 5. 


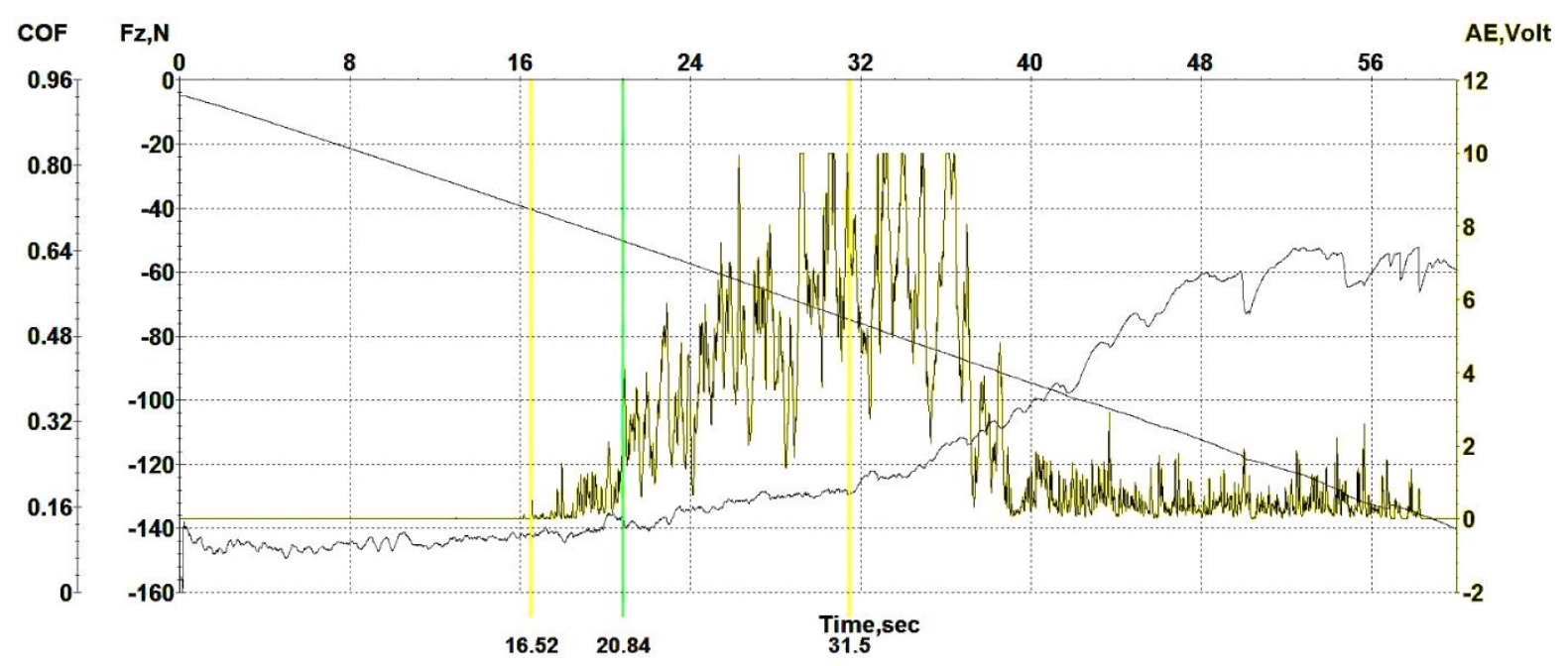

Figure 9 The critical loads Sample B (DLC)

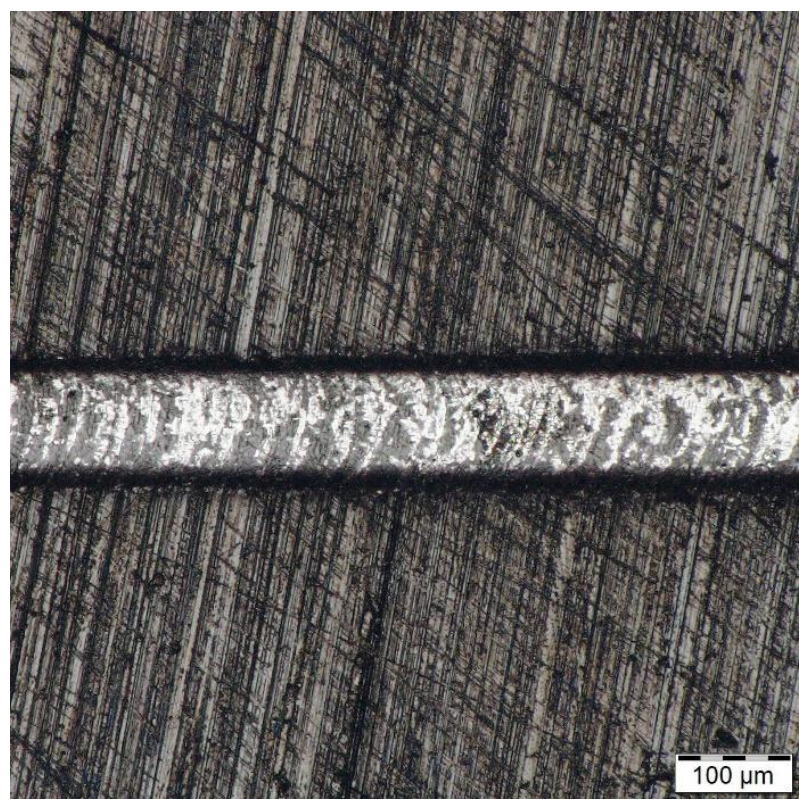

Figure 10 Sample B (DLC), 1st critical point

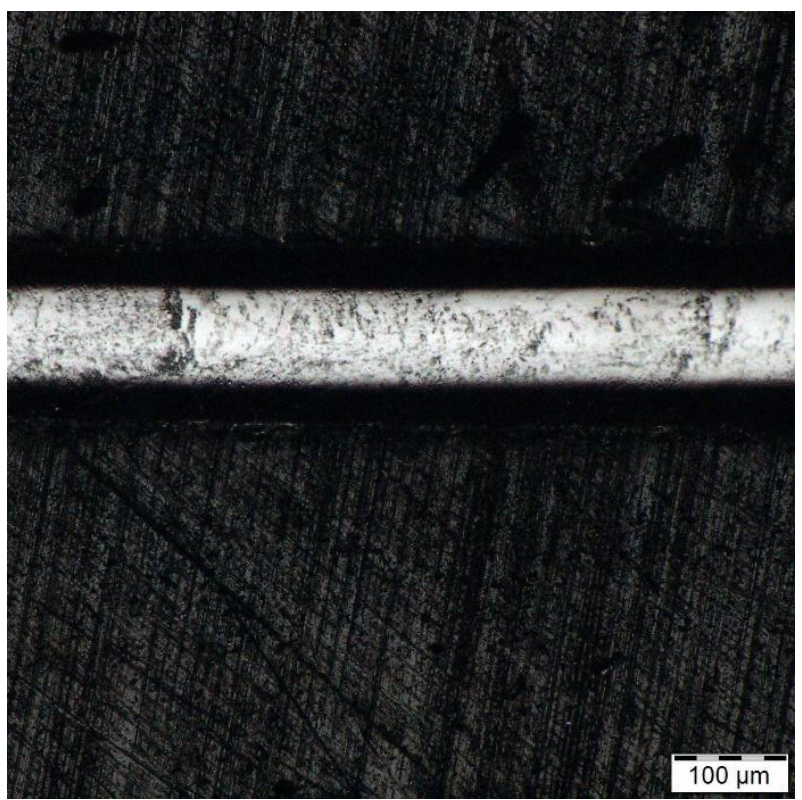

Figure 11 Sample B (DLC), 2nd critical point

Table 5 - Critical values of forces

\begin{tabular}{|c|c|c|}
\hline Sample & Rupture of coating [N] & Break of coating [N] \\
\hline A (PN + DLC) & 40 & 71 \\
\hline B (DLC) & 54 & 94 \\
\hline
\end{tabular}

\section{CONCLUSION}

Coatings and layers parameters were evaluated on samples. The samples were made in the form of flat rotary disks. These samples were evaluated by metallography and course of the microhardness of the surface into the core material. Tribological properties, i.e. the coefficient of friction, the coefficient of wear by the "Ball on Disc" method and the scratch resistance by the Scratch test were also evaluated. 
Microhardness measurements clearly showed that sample A (PN + DLC) was tempered due to plasma nitriding. Samples with duplex system A (PN + DLC) and sample B coated with DLC achieved the same microhardness values of approximately $750 \mathrm{HV} 0.1$ across the sample.

The friction coefficient of all samples was measured at three load levels, namely $(5,20$ and 50$) \mathrm{N}$. For both measured samples, it has been shown that at all load levels, they have a minimum rise, in units of meters, to a stable friction coefficient value. This value is approximately 0,1 and is stable over the $500 \mathrm{~m}$ test track. The results of the measurements show a very fast leveling of the friction pairs and stabilization of the tribological conditions between the indentor and the surface of the test sample.

The wear coefficient was calculated using formula (1). For this purpose, the track contents of the individual "Ball on Disc" exams were measured. The measurement of the trace contents was problematic because of their unclear shape, very difficult to distinguish from the roughness around the trace. Therefore, it is hard to precisely determine the coefficient values for the DLC coating. The results of the wear coefficient are in accord with the previous data obtained during testing of the coatings and their structural condition.

Results from scratch test confirm previous results obtained in tribological testing of coatings of samples $A$ and B. Higher critical rupture and breakage forces were measured for the DLC coating of Sample B compared to the Sample A duplex system.

Based on the observed and measured values by the above mentioned technologies and methods of measurement it can be clearly stated that the DLC coating is the most suitable for practical application. Relatively similar results can also be achieved by applying a plasma nitriding + DLC coating duplex system (sample B). However, this application of the coating is related to the prolonged deposition time of the coating and increased financial demands. The practical importance is then questionable and the suitability of its use depends on the specific application, e.g. in relation to military technology.

\section{ACKNOWLEDGEMENTS}

The paper has been prepared thanks to the support of the project The Development of Technologies, Design of Firearms, Ammunition, Instrumentation, Engineering of Materials and Military Infrastructure "VÝZBROJ (DZRO K201)" and Surface technology in applications special techniques sV20-216.

\section{REFERENCES}

[1] POKORNÝ, Z., DOBROCKÝ, D., KADLEC, J., STUDENÝ, Z. Influence of alloying elements on gas nitriding process of high-stressed machine parts of weapons. Kovove Materialy-Metallic Materials. 2018, 56(2), 97-103. ISSN 0023-432X.

[2] POKORNÝ, Z., KADLEC, J., STUDENÝ, Z., POSPÍCHAL, M., DOBROCKÝ, D. Solid state diffusion of nitrogen and carbon in the fe-c system. In METAL 2016: 25th Anniversary International Conference on Metallurgy and Materials. TANGER Ltd., Ostrava: TANGER Ltd., 2016, p. 1151-1156. ISBN 978-80-87294-67-3.

[3] POKORNÝ, Z., STUDENÝ, Z., POSPÍCHAL, M., HRUBÝ, V., JOSKA, Z. Characteristics of plasma nitrided layers. Manufacturing Technology, 2015, 15(3), 403-409. ISSN 1213-2489.

[4] POSPÍCHAL, M., DVOŘÁKOVÁ, R., STUDENÝ, Z., POKORNÝ, Z. Influence of Initial Carbon Concentration on Nitride Layers. Manufacturing Technology. 2015, 15(5), 889-893. ISSN 1213-2489.

[5] BARÉNYI, I., MAJERÍK, J., POKORNÝ, Z., SEDLÁK, J., et al. Material and technological investigation of machined surfaces of the OCHN3MFA steel. Metallic Materials. 2019, 57(2), 131-142. ISSN 0023-432X.

[6] KUSMIČ, D., DOBROCKÝ, D. Corrosion Resistance of Plasma Nitrided Structural Steels. Manufacturing Technology. 2015, 15(1), 64-69. ISSN 1213-2489. 
[7] DOBROCKÝ, D., KUSMIČ, D. The Assessment of Selected Mechanical Properties of Steel after Application of Plasma Nitriding. In: Materiály a technologie ve výrobě speciální techniky. Brno, Czech Republic: UO Brno, 2015, p. 31-38. ISBN 978-80-7231-999-2.

[8] FOnTES, M. A., PereirA, R. G., FernandeZ, F. A. P., CASTEletTI, L. C., NAScente, P. A. de P.: Characterization of plasma nitrided layers produced on sintered iron. In: Journal of Materials Research and Technology. vol. 88, 2014, p. 1-7.

[9] KLANICA, O., DOBROCKÝ, D., ONDERKA, F. The changes of surface texture parameters of the duplex systems: nitrided layer - coating at CoCrMo alloy. In: ECS Transaction 15th ABAF BRNO 2014 Advanced Batteries, Accumulators and Fuel Cells. Brno: Electrochemical Society Inc., 2014, p. 255-259. ISSN 1938-5862.

[10] POKORNÝ, Z., KADLEC, J., HRUBÝ, V., JOSKA, Z., TRAN, Q. D., BERAN, D. Plasma nitriding of bored Barrels. Advances in Military Technology, 2011, 6(1), 69-76. ISSN 1802-2308.

[11] FATTAH, M., MAHBOUBI, F. Comparison of ferritic and austenitic plasma nitriding and nitrocarburising behavior of AISI 4140 low alloy steel. Materials and Design. 2010, 31, 8, s. 3915-3921. ISSN 0261-3069.

[12] FIŠEROVÁ, E., CHVOSTEKOVÁ, M., BĚLAŠKOVÁ, S., BUMBÁLEK, M., JOSKA, Z. Survival Analysis of Factors Influencing Cyclic Fatigue of Nickel-Titanium Endodontic Instruments. Advances in Materials Science and Engineering (2015) 2015. DOI: 10.1155/2015/189703

[13] WACHOWSKI, M., SNIEZEK, L., SZACHOGLUCHOWICZ, I., KOSTUREK, R., PLOCINSKI, T. Microstructure and fatigue life of $\mathrm{Cp}-\mathrm{Ti} / 316 \mathrm{~L}$ bimetallic joints obtained by means of explosive welding. Bulletin of the Polish Academy of Sciences: Technical Sciences in 2018, vol. 66, no. 6., p. 925 - 933. ISSN 2300-1917. DOI 10.24425/bpas.2018.125940

[14] ASTM G 99 95a Standard Test Method for Wear Testing with a Pin-on-Disk Apparatus

[15] ASTM G 171 - 03 Standard Test Method for Scratch Hardness of Materials Using a Diamond Stylus1

[16] ZAČAL, J., DOSTÁL, P., ŠUSTR, M., DOBROCKÝ, D. Acoustic Emission During Tensile Testing Of Composite Materials. Acta Universitatis Agriculturae et Silviculturae Mendelianae Brunensis, 2017, 65(4), 1309-1315. ISSN 1211-8516. 